\title{
The Biological Evaluation of the Effects of Waste Dump in River Ona Apata, Ibadan on Liver, Kidney and Haematological Parameters of Albino Rats
}

\author{
*Alabi T.D. ${ }^{1}$, Oloyede O.B. ${ }^{2}$, Sunmonu T.O. ${ }^{2}$ And Makinwa T.T. ${ }^{1}$ \\ ${ }^{1}$ (Department of Chemical Sciences, College of Natural and Applied Sciences, Achievers University, Owo, Ondo \\ State, Nigeria.) \\ ${ }^{2}$ (Department of Biochemistry, Faculty of Sciences, University of Ilorin, Ilorin, Kwara State, Nigeria.)
}

\begin{abstract}
River Ona, Apata, Ibadan is a water body used for a lot of domestic purposes. In this study the physicochemical properties of River Ona and tap water were determined as well as their effects on liver and kidney of albino rats. The heamotological parameters were also studied. Thirty albino rats used for this study were grouped into five. Rats in group 1 served as control and were administered tap water ad-libitum, while rats in groups 2-5 were administered River Ona water in varying concentrations $(25 \% \mathrm{v}, 50 \% \mathrm{v} / v, 75 \% \mathrm{v} / v$ and $100 \% \mathrm{v}$ ) for 20 days. The physicochemical test results revealed that the colour, turbidity, total dissolved solids, chloride were significantly $(p<0.05)$ higher than the W.H.O. standards while $p H$, sulphate, magnesium, copper were significantly $(p<0.05)$ lower, manganese and cadmium were not detectable. A significant increase in the specific activity of Alkaline phosphatase relative to the control was observed. Whereas a significant ( $p<0.05)$ decrease in the specific activity of Alanine transaminase, the concentrations of Heamoglobin, Pack Cell Volume, Red Blood Cell, Mean Cell Volume, White Blood Cell, Platelets, Neutrophils and Lymphocytes was observed. These results suggest that the use and intake of water obtained from River Ona may predispose the liver and kidney to damage; also it might lead to compromised immune system.
\end{abstract}

Key words: Haematological, Physicochemical, River Ona, Sewage.

\section{Introduction}

The environment is nature's most benevolent gift to human existence on earth. Land, water and air are the major components of environment; the environment is abused by man through indiscriminate disposal of domestic, commercial and industrial wastes which results to diseases and epidemic. The rate and extent of pollution in the environment is on the increase. It has dangerous effects on human health, harms living resources, disrupts the ecosystem; impair amenities and other legitimate uses of the environment. Water pollution is a major problem in the global context. Water pollution is the introduction of foreign matter such as microorganisms, chemicals and industrial [1] or other waste into the environment and renders it unfits for its intended use. This makes the evaluation of the water quality highly important so as to show its biological, physical attributes and to know the effects it has on living organisms. Causes and characteristics of water pollution include industries discharge [1], sewage disposal [2], landfills and leachates [3], surface run-off and oil spill [4]. Some of the principal sources of water pollution are sewage (and other oxygen-demanding waste which is largely carbonaceous organic material whose decomposition leads to oxygen depletion), infectious agents, plant nutrients (that can stimulate the growth of plant, which on decay depletes the dissolved oxygen and produce disagreeable odours), exotic organic chemicals which include pesticides and industrial wastes, petroleum [5] and radioactive substances such as wastes from uranium and thorium mining and refining. Although, natural phenomena such as volcanoes, algae bloom, storms, earthquakes also cause changes in water pollution. Several studies have been carried out on River Ona to assess the impact of pollution on the surface water quality and it was established from the results that industrial discharges and sewage disposal had negative impact on the surface water qualities [1][2]. In this present study, an attempt is made to evaluate the effect of refuse dump and domestic waste on liver, kidney and some hematological parameters. The choice of River Ona is borne out of the fact that it is being used for domestic purposes such as cooking, washing and drinking by the inhabitants of the area.

\subsection{Experimental Water}

\section{Materials And Method}

The water used in this study was obtained from River Ona, located along Apata Road, Ibadan, Nigeria. The water was collected from several points along the river course and homogenously mixed together. The water as taken from the river is said to be $100 \%$. The collected sample was diluted using distilled water to obtain various concentrations; $25 \% \mathrm{v} / \mathrm{v}, 50 \% \mathrm{v} / \mathrm{v}, 75 \% \mathrm{v} / \mathrm{v}$ and $100 \% \mathrm{v} / \mathrm{v}$ of the sample. 


\subsection{Experimental Animals}

Albino rats were obtained from the Animal Holding Unit of the Department of Biochemistry, University of Ilorin, Nigeria. A total of thirty albino rats were acclimatized and used for this study. After acclimatization for one week, the rats were grouped into five of six animals each. Rats in group 1 served as the control and were given tap water ad libitum. Those in other groups received various concentrations of the water ad libitum. The rats were fed on pellets for twenty days.

\subsection{Physicochemical Properties}

Samples of water from River Ona and tap water were analyzed for their physicochemical properties in accordance with standard methods [6]. The metals were assayed using the Atomic Absorption Spectrophotometer. The parameters evaluated include $\mathrm{pH}$, conductivity, colour, turbidity, total dissolved solid, macro and micro elements and some heavy metals.

\subsection{Collection of Blood Samples and Tissues}

At the end of three weeks, all rats were fasted overnight and sacrificed by humane method using chloroform as anesthesia. The blood samples were collected into heparinized bottles.

\subsection{Determination of Haematological Parameters}

The Automated Haematologic Analyzer (Sysmex KX - 21) was used to analyze certain hematological indices such as Red Blood Cell, Pack Cell Volume, Mean Cell Volume, Hemoglobin concentration amongst others. The analyses were carried out based on standard methods [7][8].

\subsection{Preparation of Tissue Homogenates}

The liver and kidney were excised and weighed. The organ to body weight ratio was determined. The organs were homogenized in four parts of the homogenizing buffer (0.1M phosphate buffer, $\mathrm{pH}$ 7.4).

\subsection{Enzyme Assays}

The activity of alkaline phosphatase (ALP) in the kidney was determined using the method of Wright et al., [9], while the activity of Alanine Aminotransferase (ALT) in the liver was measured using the method described by Schmidt and Schmidt [10].

\subsection{Statistical Analysis}

All data were analyzed statistically using analysis of variance (ANOVA). All results were expressed as mean \pm SD with a significant level at $\mathrm{p}<0.05$ using Duncan's Multiple Range Test [11].

All chemical and reagents used in this study were of analytical grades.

\section{Results}

The results of the experiment revealed some of the physicochemical parameters carried out on River Ona water, tap water in comparison with WHO standards (TABLE 1). There was a significant decrease in $\mathrm{pH}$ and sulphate when compared with WHO standards, while total dissolved solids, colour and turbidity significantly $(\mathrm{p}<0.05)$ increased.

TABLE 2 reveals the mean values of \%age organ-body weight ratio of rats placed on various concentrations of samples from River Ona. There was a non-significant decrease in the liver, kidney-body weight ratio of rats placed on $25 \% \mathrm{v} / \mathrm{v}, 50 \% \mathrm{v} / \mathrm{v}, 75 \% \mathrm{v} / \mathrm{v}$ concentrations of River Ona when compared with the control, while a significant reduction was observed in the group placed on $100 \% \mathrm{v} / \mathrm{v}$ concentration of River Ona.

TABLE 3 presents the mean values of the specific activity of alkaline phosphatase in the kidney of rats placed on $25 \% \mathrm{v} / \mathrm{v}, 50 \% \mathrm{v} / \mathrm{v}$, and $75 \% \mathrm{v} / \mathrm{v}$ concentrations of River Ona. It was observed that there was a significant increase in the specific activity of alkaline phosphatase in the kidney of rats placed on $100 \% \mathrm{v} / \mathrm{v}$ concentration of River Ona when compared with the control.

The mean values of the specific activity of alanine transaminase in the liver of rats placed on different concentrations of River Ona are shown in TABLE 4. The specific activity of alanine transaminase reduced significantly $(\mathrm{p}<0.05)$ in the liver of groups placed on $25 \% \mathrm{v} / \mathrm{v}, 50 \% \mathrm{v} / \mathrm{v}, 75 \% \mathrm{v} / \mathrm{v}$ and $100 \% \mathrm{v} / \mathrm{v}$ concentrations of River Ona relative to the control.

The result of some hematological test carried out on blood samples of rats placed on $25 \% \mathrm{v} / \mathrm{v}, 50 \% \mathrm{v} / \mathrm{v}$, $75 \% \mathrm{v} / \mathrm{v}$ and $100 \% \mathrm{v} / \mathrm{v}$ concentrations of River Ona and control group revealed that there was a significant $(\mathrm{p}<0.05)$ decrease in the mean concentrations of haemoglobin, pack cell volume (PCV), mean cell volume (MCV), white blood cell (WBC), platelets, neutrophils and lymphocytes of rats placed on $25 \% \mathrm{v} / \mathrm{v}, 50 \% \mathrm{v} / \mathrm{v}$, 
The Biological Evaluation Of The Effects Of Waste Dump In River Ona Apata, Ibadan On Liver,

$75 \% \mathrm{v} / \mathrm{v}$ and $100 \% \mathrm{v} / \mathrm{v}$ concentration of River Ona relative to control, while no change was observed in the mean concentration of mean cell haemoglobin $(\mathrm{MCH})$ and mean cell haemoglobin concentration (TABLE 5).

TABLE 1: Physicochemical characteristics of River Ona water and tap water using WHO values as standards

\begin{tabular}{|lllll|}
\hline \multicolumn{1}{|c}{ Parameters } & River Ona & Tap water & WHO standards & MPC \\
\hline $\mathrm{pH}$ & 6.95 & 7.60 & 7.80 & - \\
\hline Colour (pt/Co units) & 35 & 25 & 20.27 & 30 \\
\hline Turbidity (FTU) & 7 & 4 & 3.5 & 6 \\
\hline Total Dissolved Solid (mg/l) & 44.6 & 35 & ND & ND \\
\hline Chloride (mg/l) & 32.6 & 35 & ND & ND \\
\hline Nitrate (mg/l) & 9.7 & 0.06 & ND & $50-100$ \\
\hline Sulphate (mg/l) & 16.1 & 39 & 200 & 400 \\
\hline Magnesium (mg/l) & 8.6 & 0.47 & 50 & 150 \\
\hline Iron (mg/l) & 0.34 & 0.01 & 0.3 & 1.3 \\
\hline Lead (mg/l) & 0.02 & $<0.05$ & ND & 0.1 \\
\hline Copper (mg/l) & 0.31 & $<0.002$ & 1.0 & 1.5 \\
\hline Manganese (mg/l) & Nil & 0.04 & 0.1 & 0.5 \\
\hline Cadmium (mg/l) & Nil & $<0.002$ & ND & ND \\
\hline
\end{tabular}

RMC- Recommendable minimum concentration

MPC- Maximum permeable concentration

ND- Not Detectable

TABLE 2: Organ to Body Weight ratio of rats placed on tap water and various concentrations of River Ona water

\begin{tabular}{|lll|}
\hline Concentration & Liver: Body weight & Kidney: Body weight \\
\hline Control & $33.03 \pm 0.04$ & $7.79 \pm 0.08^{\mathrm{a}}$ \\
\hline $25 \%$ & $32.66 \pm 0.08^{\mathrm{a}}$ & $7.23 \pm 0.09^{\mathrm{b}}$ \\
\hline $50 \%$ & $31.22 \pm 0.08^{\mathrm{b}}$ & $7.22 \pm 0.08^{\mathrm{b}}$ \\
\hline $75 \%$ & $31.06 \pm 0.05^{\mathrm{b}}$ & $7.08 \pm 0.00^{\mathrm{c}}$ \\
\hline $100 \%$ & $30.86 \pm 0.01^{\mathrm{c}}$ & $6.83 \pm 0.09^{\mathrm{d}}$ \\
\hline
\end{tabular}

Results are mean \pm SD for rats. Values with different superscripts are significantly $(\mathrm{p}<0.05)$ different.

TABLE 3:Specific activity of Alkaline Phosphatase in the Kidney of Rats placed on tap water and various concentration of polluted River Ona water.

\begin{tabular}{|lc|}
\hline Concentrations & Specific Activity (I $\mu / \mathrm{mg}$ protein) \\
\hline Control & $79.33 \pm 1.86^{\mathrm{a}}$ \\
\hline $25 \%$ & $95.33 \pm 2.24^{\mathrm{b}}$ \\
\hline $50 \%$ & $107.33 \pm 1.61^{\mathrm{c}}$ \\
\hline $75 \%$ & $112.33 \pm 1.19^{\mathrm{d}}$ \\
\hline $100 \%$ & $214.67 \pm 1.40^{\mathrm{e}}$ \\
\hline
\end{tabular}

Results are mean \pm SD for rats. Values with different superscripts are significantly $(\mathrm{p}<0.05)$ different.

TABLE 4: Specific Activity of Alanine transaminase in the liver of rats placed on tap water and various concentrations of polluted River Ona water

\begin{tabular}{|l|l|}
\hline Concentrations & Specific Activity x $10^{-3}(\mathrm{I} \mu / \mathrm{mg}$ protein $)$ \\
\hline Control & $8.81 \pm 0.24^{\mathrm{a}}$ \\
\hline $25 \%$ & $4.29 \pm 0.38^{\mathrm{b}}$ \\
\hline $50 \%$ & $2.76 \pm 0.17^{\mathrm{c}}$ \\
\hline $75 \%$ & $1.62 \pm 0.03^{\mathrm{d}}$ \\
\hline $100 \%$ & $1.39 \pm 0.01^{\mathrm{e}}$ \\
\hline
\end{tabular}

Results are mean \pm SD for rats. Values with different superscripts are significantly $(\mathrm{p}<0.05)$ different. 
The Biological Evaluation Of The Effects Of Waste Dump In River Ona Apata, Ibadan On Liver,

TABLE 5: Haematological Parameters of rats placed on tap water and various Concentrations of polluted

\begin{tabular}{|c|c|c|c|c|c|c|c|c|c|c|}
\hline \multicolumn{11}{|c|}{ River Ona water } \\
\hline Conc. & $\begin{array}{l}\mathrm{Hb} \\
(\mathrm{g} / \mathrm{dL})\end{array}$ & $\begin{array}{l}\text { PCV } \\
\text { (\%age) }\end{array}$ & $\begin{array}{l}\mathrm{RBC} \\
(\mathrm{X} \\
\left.10^{12} / \mathrm{L}\right)\end{array}$ & $\begin{array}{l}\text { MCV } \\
(\mathrm{cL})\end{array}$ & $\begin{array}{l}\mathrm{MCH} \\
(\mathrm{g} / \mathrm{dL})\end{array}$ & $\begin{array}{l}\text { MCHC } \\
\text { (\%age) }\end{array}$ & $\begin{array}{l}\text { WBC } \\
\left(\mathrm{X} 10^{9} / \mathrm{L}\right)\end{array}$ & $\begin{array}{l}\text { Plat } \\
\left(\mathrm{X} 10^{9} / \mathrm{L}\right)\end{array}$ & $\begin{array}{l}\text { Neut } \\
\text { (\%age) }\end{array}$ & $\begin{array}{l}\text { Lymph } \\
\text { (\%age) }\end{array}$ \\
\hline Control & $13.97 \pm 0.09$ & $47.50 \pm 0.12$ & $7.46 \pm 0.57$ & $67.00 \pm 0.60$ & $19.67 \pm 0.58$ & $29.30 \pm 0.58$ & $11.57 \pm 0.05$ & $564.67 \pm 2.32$ & $32.67 \pm 0.52$ & $87.33 \pm 0.52$ \\
\hline $25 \%$ & $12.23 \pm 0.08$ & $37.33 \pm 0.08$ & $5.92 \pm 0.35$ & $63.00 \pm 0.46$ & $19.67 \pm 0.58$ & $30.00 \pm 1.00$ & $10.57 \pm 0.06$ & $472.67 \pm 4.31$ & $16.33 \pm 0.52$ & $83.67 \pm 0.52$ \\
\hline $50 \%$ & $11.77 \pm 0.01$ & $35.33 \pm 0.31$ & $5.56 \pm 0.15$ & $62.33 \pm 0.15$ & $19.00 \pm 0.00$ & $30.00 \pm 0.00$ & $9.87 \pm 0.05$ & $438.67 \pm 2.86$ & $13.33 \pm 0.52$ & $77.33 \pm 0.08$ \\
\hline $75 \%$ & $11.50 \pm 0.03$ & $34.67 \pm 0.04$ & $5.33 \pm 0.04$ & $56.67 \pm 0.15$ & $19.00 \pm 0.00$ & $30.00 \pm 0.00$ & $8.73 \pm 0.09$ & $344.33 \pm 3.20$ & $12.67 \pm 0.08$ & $65.67 \pm 0.89$ \\
\hline $100 \%$ & $11.33 \pm 0.04$ & $31.33 \pm 0.15$ & $4.61 \pm 0.19$ & $52.67 \pm 0.08$ & $19.00 \pm 0.00$ & $30.00 \pm 0.00$ & $6.40 \pm 0.00$ & $317.67 \pm 1.10$ & $7.67 \pm 0.15$ & $62.33 \pm 0.15$ \\
\hline
\end{tabular}

Results are mean \pm SD for rats. Values with different superscripts are significantly $(\mathrm{p}<0.05)$ different.

\section{Discussion}

Pollution of water bodies is assuming alarming proportions with increased population, industrialization, urbanization and intensive agriculture [12]. It includes not only the influences of plants and animals present but also those of the physico-chemical and materiological factors [13]. TABLE 1 shows the result of some physicochemical tests carried out on samples from River Ona and tap water used as control in comparison with WHO permissive standards. It was observed that the $\mathrm{pH}$ of the river ona water sample is slightly acidic, the colour is above normal and the total dissolved solid is high when compared with WHO standards while the $\mathrm{pH}$ and colour of the tap water falls within the normal range when compared with WHO standards. This is in correlation with a previous study by Oladele et al [1]. Other parameters compare favourably with the tap water and WHO standards. However the slight decrease in the $\mathrm{pH}$ of River Ona water and the deviation from the normal water colour may be due to the fact that most of the dissolved solids, products of decomposition of organic materials and chemicals are retained in the river. Moreover, the odour and taste of the water cannot be changed no matter how rapid it flows. Although, some of the residents believed that boiling of the water makes it safe, conversely heating of this water may not eliminate the chemicals or organic toxins that are present as suggested by Curtis and Pidwirny [14] in a previous study.

TABLE 2 presents the organ to body weight ratio of rats placed on different concentrations water from River Ona and tap water. There was a non-significant decrease in the liver to body weight ratio between the control and rats placed on $25 \% \mathrm{v} / \mathrm{v}, 50 \% \mathrm{v} / \mathrm{v}$, and $75 \% \mathrm{v} / \mathrm{v}$, but a significant decrease was observed in the group placed on $100 \%$ River Ona water. There was a progressive reduction in the kidney to body weight and a more significant decrease in the group placed on $100 \% \mathrm{v} / \mathrm{v}$ River Ona water. This is in line with the work of Barnes and Denz [15], where it was established that changes in organ weight is one of the criteria of toxicity and diseased condition.

Alkaline phosphatase is increased in obstructive liver diseases, but it is not specific for the liver. Increases of a similar magnitude (three- to five-fold normal) are commonly seen in bone diseases leukemia, and some other malignancies. TABLE 3 presents the result of the specific activity of alkaline phosphatase in the kidney of rats placed on tap water and River Ona water. It is observed that there was an increase in the activity of alkaline phosphatase when compared with the control. This may be indicative of high rate of metabolism, absorption and elimination due to the presence of some toxic materials in the water such as insecticides, pesticides and some toxins produced by microorganism leading to increased production of alkaline phosphatase in the kidney.

Transaminases are well-known enzymes used as biomarkers to predict possible toxicity [16]. Generally, damage to liver cells will result in elevations of these transaminases in the serum [17]. Furthermore, measurement of enzymic activities of ALT is of clinical and toxicological importance as changes in its activities are indicative of liver damage by toxicants or a diseased condition [18]. TABLE 4 shows the specific activity of alanine transaminase in the liver of rats placed on tap water and River Ona water. The specific activity of alanine transaminase reduced significantly $(p<0.05)$ relative to the control, the observed decrease in the activities of liver AST suggests that there may be a leakage of these enzymes from the liver to the serum [19].

The results of haematological test carried out on the blood samples of rats placed on tap water and different concentrations of River Ona water is presented in TABLE 5. The data revealed that haemoglobin, mean cell volume and red blood cell concentration reduced significantly $(\mathrm{p}<0.05)$ as the concentration of the River Ona water increases. This is likely due to the destruction of red blood cells by microbes present in the water and toxicity of the water to the bone marrow, so that fewer red blood cells are produced leading to anaemic condition. This corroborates with previous research carried out by Joseph et al.,[20] whose study shows that there is a reduction in the total RBC in animals with bacterial and fungal infection, this is also supported by Biggs et al., [21] whose findings shows that anaemia develops during infection. The white blood cells (neutrophils, lymphocytes) and platelets which act as a defense for the body against infectious diseases and foreign materials [22] were significantly $(\mathrm{p}<0.05)$ reduced, when compared with the control. This observation is similar to the findings of Ovuru and Ekweozor [23] where WBC decreased with an increase in crude oil 
contamination in experimental rabbits. The result of this study is also in agreement with the findings of Ngodigha et al. [24] who observed a reduction in total white blood cell in goats as the level of crude oil contamination increased.

Also, the lymphocytes concentration decreased significantly $(\mathrm{p}<0.05)$ as the concentration of Ona water increases, this is indicative of reduced immunity to viral infections because lymphocytes produce antibodies against viral infections [25].

\section{Conclusion}

From this study, it can be concluded that the intake and use of Ona water can lead to anaemic conditions as seen by the significant reduction of the red blood cell concentration and the pack cell volume. Also, it can result to decreased immunity as shown by the significant reduction in the white blood cells. Intake of River Ona water over a long period of time can lead to liver and kidney damage as depicted by the decreased activity of alanine transaminase in the liver and increased activity of alkaline phosphatase in the kidney.

\section{Recommendation}

The value of reusing, recycling and composting solid waste is clear when you consider the damage such materials pose to the environment and human health at large. The Nigerian government should enforce implementation of environmental policies that enhances land use such as Land Use Act; 1978, Oil in Navigable Water Decree; 1967, Sea Fisheries Decree; 1991 and take legal actions against anyone who violates these policies. Also, the government and other non-governmental organizations should enlighten communities and the nation at large especially where they are dependent on natural water resources for survival, on the effects and damages caused by using polluted water resources. In lieu of this, the government should provide quality and adequate tap water.

\section{References}

[1] O. Oladele, P.D. Adegbenro, and M.G. Adewole, The impact of industries on surface water quality of River Ona and River Alaro in Oluyole Industrial Estate, Ibadan, Nigeria. African Journal of Biotechnology, 10 (4), 2011, 696-702.

[2] K. Ogedengbe, and C. Akinbile, Comparative Analysis of the Impact of Industrial and Agricultural Effluent on Ona Stream in Ibadan, Nigeria. New York Science Journal, 3(7), 2010, 25 - 33.

[3] G.M. Hudges, Hydrologic Considerations in the Citing and Design of Landfills, Environmental Geology, (Notes, no 51 Urbana: Illinois State Geological Survey, 1972).

[4] T.O. Sunmonu, O.B. Oloyede, Haematological Response of African Catfish (Clariasgariepinus) and Rat to Crude Oil Exposure, The Internet Journal of Hematology, 4(1), 2008.

[5] B.J. Alloway, and D.C. Ayres, Chemical Principles of Environmental Pollution. (Blackie Academic and Professional, CRC Press, 1997) 190-220.

[6] APHA, Standard Method for Examination of Water and Wastewater, $18^{\text {th }}$ edition (Washington, D C: American Public Health Association, 1992).

[7] J.V. Dacie, and S.M. Lewis, Practical Haematology, 5th edition (London: Churchill Livingstone, 1975).

[8] R.R. Alexander, and J.M. Griffiths, Haematocrit, In Basic Biochemical Methods, 2nd edn. (New York: JohnWilley and Sons Inc., 1993 ) 186 $-189$.

[9] P.J. Wright, A.O. Leathwood, D.T. Plummer, Enzymes in rat urine: alkaline phosphates. Enzymologia, 42, $1972,317-327$.

[10] E. Schmidt, F.W. Schmidt, Determination of serum GOT and GPT activities in Enzyme. Biol. Clin. 3, 1963, 1-5.

[11] D.B. Duncan, Multiple range and multiple F test. Biometals 11, 1955, 1-10.

[12] G.V. Venkataraman, P.N.S. Rani, N.S. Raju, S.T. Girisha and B.V. Raghavendra, Physico-chemical characteristics and impact of aquatic pollutants on the vital organs of a freshwater fish Glossogobiusgiuris. Res. J. Environ. Toxicol. 1, 2007, 1-15.

[13] B. Velmurugan, M. Selvanayagam, E.I. Cengiz, and E. Unlu, Histopathology of lambda- cyhalothrin on tissues (gill, kidney, liver and intestine) of Cirrhinusmrigala. Environ. Toxicol. Pharmacol, 24, 2007, 286-291.

[14] P.J. Curtis, and M. Pidwirny, British Columbia stream survey for dissolved organic matter: Summer baseflow conditions,Final Report. National Hydrology Research Institute, Environment Canada, 2000.

[15] J.M. Barnes, and F.A. Denz, Experimental Methods used in determining chronictoxicity. A critical review pharmacology. Rev. 6(222), 1954, 273-283.

[16] M.F. Rahman, M.K. Siddiqui, K. Jamil, Effects of vepacide (Azadirachtaindica) on aspartate and alanine aminotransferase profiles in subchronic study with rats. J. Hum. Exp. Toxicol. 20, 2001, 243-249.

[17] P.L. Wolf, D. Williams, T. Tsudaka, L. Acosta, Methods and Techniques in Clinical Chemistry (John Wiley \& Sons, USA, 1972).

[18] N.S. Singh, P. Vats, S. Suri, R. Shyam, M.M.L. Kumria, S. Ranganathan, and K. Sridharan, Effect of an antidiabetic extract of Catharanthusroseus on enzymic activities in streptozotocin induced diabetic rats. Journal of Ethnopharmacology, 76, 2001, $269-277$.

[19] K.S. Hanley, E. Schmidt, and F.M. Schmidt, Enzymes in Serum, their Volumes in Diagnosis. (Illinois, Charles Thomas Springfield, 1986) 79-81.

[20] B. Joseph, D. Pradeep, and S. Sujatha, Relative Study on Haematology, Glycogen Content and Histological Changes in Organs of Anabas testudineus from Parvathiputhanar (Polluted) and Karamana River (Fresh Water). Research Journal of Environmental Sciences, 6, 2012, 2635.

[21] J. Biggs, P. Williams, M. Whitfield, P. Nicolet, and A. Weatherby, 15 years of pond assessment in Britain: Results and lessons learned from the work of pond conservation. Aqua.Conserv. Mar. Freshwater Ecosyst., 15, 2005, 693-714.

[22] S.L. Robbins, and D. Angell, Basic Pathology. 2nd Edn, (Philadelphia-London: W.B. Saunders Co., 1976).

[23] S.S. Ovuru, and I.K.E. Ekweozor, Haematological changes associated with crude oil ingestion in experimental rabbits, African Journal of Biotechnology, 3, 2004, 346-348.

[24] E.M. Ngodigha, F.O. Olayinka, B.M. Oruwari, I.K. Ekweozor, and S.N. Wekhe, (1999): Toxic effects of crude oil on organs and blood cells of West Africa dwarf goats. Nig. Vet. J.,20, 1999, 82-91.

[25] D.M. Spain, 1975. Corticosteroids, Inflammation and Connective Tissue, in H. Blaschko, G. Sayer and A.D. Smith (Eds.), Handbook of physiology, (Washington: American Physiological Society, 1975) 